\title{
RENEWABLE ENERGY DEVELOPMENT OF SUSTAINABLE BAMBOO FOREST BASED ON COMMUNITY EMPOWERMENT
}

\author{
Johannes Wahono*)1, Ujang Sumarwan**), Bustanul Arifin ${ }^{* * *}$, and Herry Purnomo ${ }^{* * * *)}$ \\ "Business Management, BINUS Online Learning \\ Jl. K.H. Syahdan no.9 Palmerah, Jakarta 11480, Indonesia \\ ${ }^{* *}$ Department of Family and Consumer Sciences, Faculty of Human Ecology, IPB University \\ Jl. Kamper Kampus IPB Dramaga,, Bogor 16680, Indonesia \\ ${ }^{* * *}$ Agribusiness Department, Faculty of Agriculture, University of Lampung \\ Jl. Prof. Dr. Ir. Sumantri Brojonegoro, Kota Bandar Lampung, Lampung 35141, Indonesia \\ ${ }^{* * * *)}$ Forest Management, Faculty of Forestry, IPB University \\ Jl. Lingkar Akademik Kampus IPB Dramaga,, Bogor 16680, Indonesia
}

\begin{abstract}
This research aimed to study bamboo biomass renewable energy development cultivated in community forests in Indonesia, especially in those frontiers, outermost, and least developed regions often referred to as $3 \mathrm{~T}$ regions. Community empowerment refers to the process of enabling communities to increase control over their lives. The study was conducted in three villages of Matotonan, Madobag, and Saliguma in Siberut Island, Mentawai Islands District, West Sumatra Province. This study's design was descriptive by conducting a field survey, using a systematic random sampling method with the interview and questionnaire technique to obtain primary data on electricity demand and demographic factors. The key success indicators were then generated using the Strategic Assumption Surfacing and Testing (SAST) method to analyze the FGD. The biomass energy development without community empowerment and the presence of PLN at subsidized rates would not succeed. The renewable energy of bamboo forest biomass characterizes the need for community participation to be involved in operations. Without community empowerment, the community would not have the ability to pay electricity bills even if subsidized. No income distribution would also result in not achieving the main objectives of this project's development, which is sustainable development for rural communities in the $3 \mathrm{~T}$ regions.
\end{abstract}

Keywords: renewable energy, bamboo biomass, community empowerment, community forestry, sustainable development

\begin{abstract}
Abstrak: Penelitian ini untuk mengkaji pengembangan energi terbarukan biomassa tanaman bambu yang dibudidayakan di hutan berstatus hutan kemasyarakatan untuk di daerah tertinggal, terdepan dan terluar Indonesia. Pemberdayaan masyarakat adalah proses meningkatkan kemampuan mereka menentukan hidupnya lebih baik. Penelitian dilakukan di tiga desa Matotonan, Madobag dan Saliguma di Pulau Siberut Kabupaten Kepulauan Mentawai Provinsi Sumatera Barat. Desain penelitian deskriptif dengan data primer kebutuhan listrik dan faktor demografi kondisi lapangan melalui survey pada desa setempat dengan menggunakan metode systematic random sampling dilakukan teknik wawancara dan kuesioner..Kemidian dilakukan analisa dengan metode SAST (Strategic Assumption Surfacing and Testing). Hasil penelitian menunjukkan dibutuhkan adanya kepastian pasokan biomasa, pengembangan energi listrik tanpa adanya pemberdayaan masyarakat dan tanpa kehadiran PLN dengan tarif subsidi tidak akan berhasil. Energi terbarukan biomasa hutan bambu mencirikan perlu adanya partsipasi masyarakatl. Tanpa terjadi pemberdayaan masyarakat, masyarakat tidak memiliki kemampuan membayar tagihan listrik sekalipun bersubsidi. Tidak terjadi distribusi pendapatan juga akan mengakibatkan tidak tercapai tujuan utama pengembangan proyek ini untuk pembangunan berkelanjutan masyarakat desa di daerah $3 T$.
\end{abstract}

Kata kunci: energi terbarukan, biomassa bambu, pemberdayaan masyarakat, hutan kemasyarakatan, pembangunan berkelanjutan

\footnotetext{
${ }^{1}$ Alamat Korespondensi:

Email: johannes.wahono@binus.ac.id
} 


\section{INTRODUCTION}

Electrical energy is a vital energy needed in the development process. An area of development will be least developed without electricity. Every development sector, such as the industrial sector, trade, education, health to the welfare of the household now very dependent on electricity supply. It can be said that electrical energy acts as a development agent for a region. Indonesia is an archipelagic state consisting of $\pm 17,500$ large and small islands with an area of 3.1 million $\mathrm{km}^{2}$. more than 65,000 villages spread across thousands of islands, only less than half have enjoyed the country's electricity network. In the national development effort, especially in the development of electricity, renewable energy is the main factor that determines the success of sustainable development in a country. Important benefits of sustainability such as the availability of energy will improve socio-economic life and poverty reduction in developing countries (Nuhoff et al. 2016)

Renewable energy is energy that comes from energy sources produced by sustainable energy resources if managed properly, including geothermal, wind, bioenergy, sunlight, flow and waterfalls, as well as wave movements and temperature differences in the seawater layer. Renewable energy sources are environmentally friendly energy sources that do not pollute the environment and do not contribute to climate change and global warming like other traditional sources. This is the main reason why renewable energy is closely related to environmental and ecological problems. While Bioenergy is grouped into 2 major groups based on the source of raw materials (feedstock) and its conversion technology, i.e.; Generation I and Generation II Bioenergy. Generation I or often referred to as Biofuel is bioenergy which generally uses food crops-based raw materials while Generation II Bioenergy which is often called Biomass uses lignocellulosic raw materials which are very broad in source, ranging from waste to energy wood plants (energy crops).

Biomass is a renewable energy source to accelerate the uptake of its production, because basically biomass is a material produced by nature in a relatively short time through various biological processes. Biomass is expected to be a renewable energy growth engine because it can be developed more than anywhere and can be accepted according to their needs. Forest biomass is more appropriate to be developed in
Indonesia because bioenergy based on forest biomass will produce lignocellulose which can be cultivated and developed by Energy Forest Plantations/Hutan Tanaman Energi (HTE) and does not collide with food needs. HTE development will also help reduce pressure on natural forests and increase reserves, rehabilitate degraded land, and restore/protect the earth and store carbon stocks.

Energy from bamboo biomass has great potential to be an alternative to fossil fuels. Bamboo biomass has the advantage of better fuel characteristics than most biomass and is suitable for thermochemical and biochemical pathways to produce electrical energy. Bamboo is a tropical and subtropical plant that is easy and fast growing throughout Indonesia, high regenerative capacity, resistant to environmental conditions, high biomass yields and short harvest periods. Bamboo biomass deficiencies include, logistics and land requirements. This can also have a negative impact on the environment if not properly managed, therefore the selection of bamboo as a supply of special raw materials for energy needs to be carefully evaluated to avoid or minimize the risks that might occur and to make the best use of its potential in providing energy supplies sustainable.

Bamboo belongs to the grass family, which can be an explanation for why bamboo has a high growth rate. This means that when bamboo is harvested, bamboo will regrow quickly without disturbing the ecosystem. Unlike trees, bamboo stems emerge from the surface in full diameter and grow to their maximum height in the growing season (about 3 to 4 months). In the following year, the stem wall containing pulp will harden. In the third year, the stem becomes harder. Until the fifth year, the fungus can grow outside the stem and penetrate deep into and rot the stem. Until the eighth year (depending on species), mold growth will cause bamboo stems to rot and collapse. This shows that bamboo is best harvested when it is between three to seven years old (Hong et al. 2011). Bamboo is a grass, not a tree, very fast growing, allowing it to be harvested at the age of 4-7 years (Ashby, 2016).

Research conducted by Sritong et al. (2012) shows in the comparison of Higher Heating Value (HHV) or the value of energy produced from the combustion process, between the coconut shell (the highest HHV of biomass raw material) with the raw material of Gimsung and Tong bamboo stems, the results show that the HHV 
of both The bamboo, 15,700 kJ / kg and 17,585 kJ / $\mathrm{kg}$, is not much different from the HHV of the palm shell 18,466 kJ / kg. So that the biomass from bamboo is very suitable for producing electrical energy. The crucial problem in biomass energy power plant is the limitations and sustainability of raw materials for the energy conversion process. Due to limited land and high transportation costs, the business activities of these renewable energy plants are often not worth the investment (Hennig et al. 2016). Bamboo can grow in almost all fields and the rate of growth is fast, can produce high enough energy, low levels of carbon release so that bamboo and bamboo forests can be the right feedstock for developing biomass renewable energy for remote and underdeveloped areas (Youssefian and Rahbar, 2015).

The use of forest biomass for energy is generally recognized in accordance with the principles of sustainable development. Carbon that is bound in biomass is released during combustion, but is taken back again by new vegetation during photosynthesis along with the formation of carbon (Medeiros et al. 2015). There are other benefits of utilizing forest biomass for energy, e.g. security of supply and employment, but it is also recognized that there are adverse impacts on the community, forestry, and energy sector if not managed properly (Dhyani and Bhaskar, 2018). The main concern is the optimum amount of forest biomass that can be harvested for energy by preventing its adverse effects from occurring. This balance of trade-offs and sustainability will have an impact on the amount of forest biomass that can be produced for energy (Cambero and Sowlati, 2014).

Power plants must be integrated in the form of bamboo forest management, and any potential synergies between electricity production and other bamboo material handling activities such as transportation and storage logistics must be managed properly (Kerlero de Rosbo and de Bussy, 2012). Limitations on the cultivation of bamboo biomass to be sustainable are the importance of establishment and involvement of stakeholders such as nurseries and greenhouses, logistical institutions and land requirements (Ardian et al. 2018). This can also impose a negative impact on the environment if it is not managed properly, therefore, the selection of bamboo as a special raw material for energy needs to be carefully evaluated to avoid or minimize the risks that might occur (Truong and Le, 2014). Bamboo can accommodate the need for agro and environmental forest conservation, and can overcome unsustainable shifting cultivation. The distribution and growth function of bamboo biomass is no different from other wood trees but grows faster (Lobovikov et al. 2012).

The use of bamboo can be further developed for climate mitigation, erosion disaster management (Sofiana et al. 2018) and the development of remote areas to create a higher value of its products and improve the quality of life (Cidhy et al. 2015). The potential socioeconomic and environmental benefits of bamboo forests emphasize the implications for sustainable rural development (Partey et al. 2017). Bamboo is a versatile plant that can provide intelligent solutions to climate change and development for millions of rural communities (International Network for Bamboo \& Rattan, 2014).

Risks and uncertainties in decision making are a problem for green supply chain managers. This is especially true in developing countries for renewable energy (Little, 2017). Chen and Fan (2012) in their journal paper concluded that in addition to system dependency, uncertainty is another major challenge in the long-term strategic planning of sustainable biofuel supply systems (Chen and Fan, 2012). An effective supply of raw materials is very important for bioenergy production, because biomass tends to have a seasonal production cycle (Lautala et al. 2015). Efficient and versatile management of biomass supplies is essential for bioenergy success (Sharma et al. 2013). Although the government and industry recognize the importance of providing opportunities for the poor in biofuel supply, there is still considerable pressure to save costs in sustainable supply policies (Kondrasheva, 2015). Problems from poor farmers who lack basic business knowledge, and distrust of industry in government policies, add to this problem (Hall and Matos, 2010). Bamboo as part of a conservation forest contributes greatly to the carbon cycle $(\mathrm{C})$, and can be a pillar of farmers' livelihoods ( $\mathrm{Li}$ et al. 2019). It is therefore important to involve NGOs and community leaders in the early stages of the bioenergy project through transparent two-way communication that will increase community acceptance (Gold, 2011). To make the supply chain more socially responsible, it is necessary to implement supplier assessment tools and collaborative practices (Gimenez and Tachizawa, 2012). 
Renewable energy development for sustainable regional development can be pursued through renewable energy based on community bamboo forest biomass. However, previous research shows that there is still a gap between the uncertainty of renewable energy development and guaranteed supply of raw materials that can be overcome with community bamboo forest cultivation through empowering the surrounding community that can benefit the actors (Koirala et al. 2016). This study aims to close the gap above. Based on the description above, this study aims to; 1) Analyze the possibility of developing bamboo biomass renewable energy for the outermost and remote underdeveloped areas in Indonesia to overcome the uncertainty of its development. 2) Assess community's willingness to pay for the energy consumed. 3) Develop sustainable management of bamboo biomass feedstocks. Therefore, the scope of this research is limited to case study of the development of renewable energy from bamboo biomass cultivated in community forests in the Mentawai Islands Regency.

\section{METHODS}

The location of study was conducted in the Mentawai Islands Regency, on Siberut Island, South Siberut and Central Siberut Districts, Madobak, Matotonan and Saliguma Provinces of West Sumatra Province. The time for conducting research activities is from April 2015 to March 2018. There are couple reasons for choosing Mentawai as a research location; 1) This region is one of the lowest population densities in Indonesia and, separated from the mainland of the island of Sumatra, is a good example for the economic development of disadvantaged regions; 2) Has a large forest area and including bamboo forests that are suitable for biomass renewable energy materials. As seen on figure 1 . Location of Field Research Conducted.

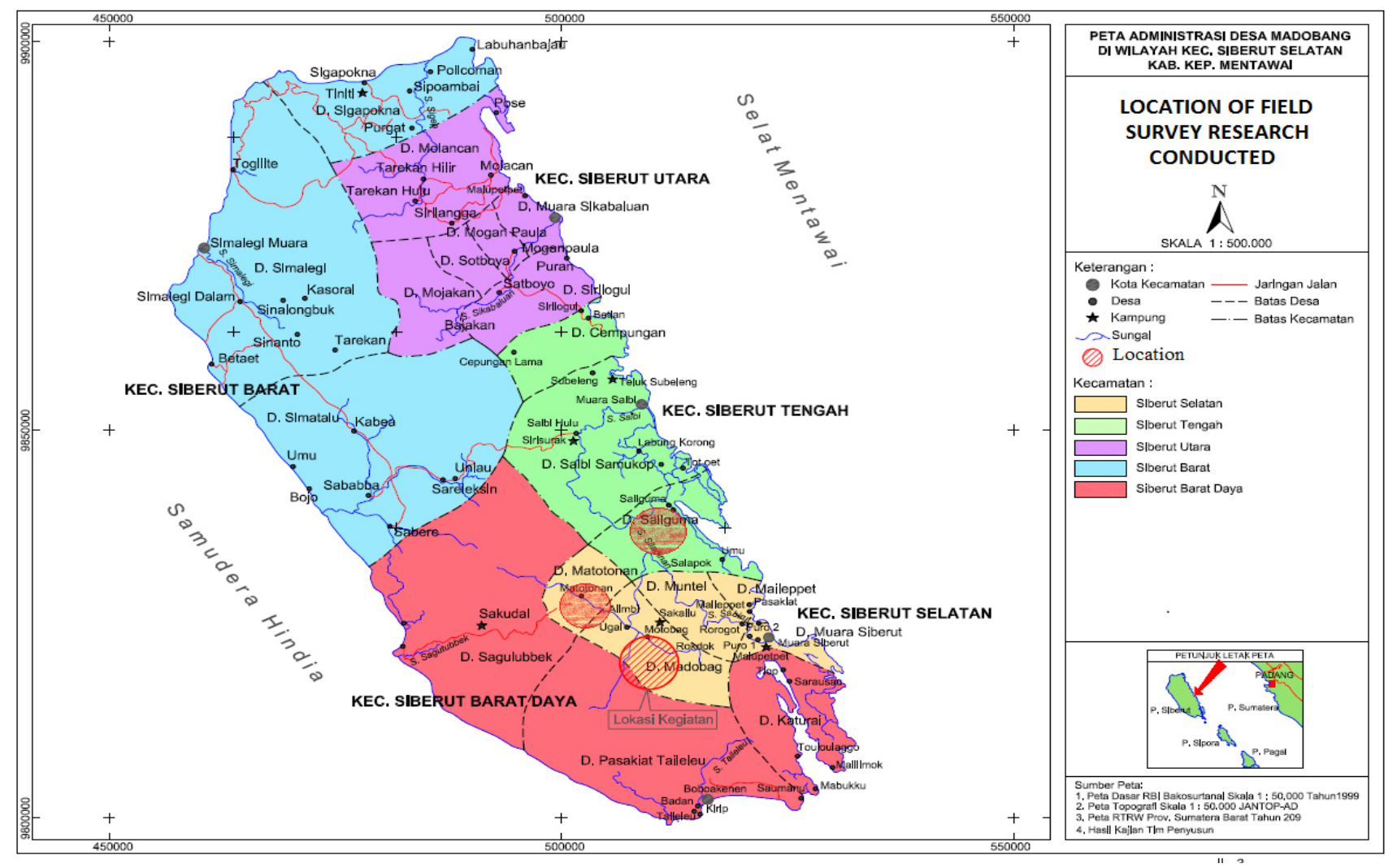

Figure 1. Location of field survey research conducted 
The design of this research is descriptive research, by conducting field surveys in the three villages that were observed to obtain primary data, then the research method using soft systems methodology techniques in the form of case studies supported by literature studies. Data collection and withdrawal is carried out to obtain data for research purposes. The data is in the form of information and knowledge from primary and secondary sources. Primary population data collection methods through surveys, sampling techniques with probability sampling using systematic random sampling methods applying interview and questionnaire techniques. Systematic random sampling is used by sorting household data in survey villages taken randomly as the first sample and then at certain intervals for the next sample, the population sample size follows the Slovin formula. Data collection in three villages was studied by sending several enumerators to carry out surveys in the field. This primary data is needed to measure and analyze population perceptions about the development of a bamboo biomass power plant in their village. Furthermore, secondary data comes from relevant agencies, periodic reports, journals, and some literature related to research. Table 1, details of population data, sampling frame and data number of samples for the three survey target villages.

Qualitative analysis was carried out with a Focus Group Discussion and in-depth interviews with experts aimed at identifying indicators of success in developing sustainable renewable energy. The analysis technique used the Strategic Assumption Surfacing and Testing (SAST) method. The stages of the research carried out were literature review, field surveys, expert surveys and focus group discussions (FGD). The FGD was conducted followed by the Strategic Assumption Surfacing and Testing (SAST) method to produce key success indicators for sustainability based on tripple buttons of sustainability i.e.; social, economic and environmental. Figure 2 is research framework that explains the research objectives, variables, data collection techniques and data analysis techniques for research results.

Table 1. Sampling Frame

\begin{tabular}{lcccc}
\hline Village & Sub-district & Population & Number of Household & Household Sample \\
\hline Madobag & Siberut Selatan & 2737 & 576 & 236 \\
Matotonan & Siberut Selatan & 1357 & 281 & 156 \\
Saliguma & Siberut Utara & 1852 & 394 & 198 \\
\hline
\end{tabular}

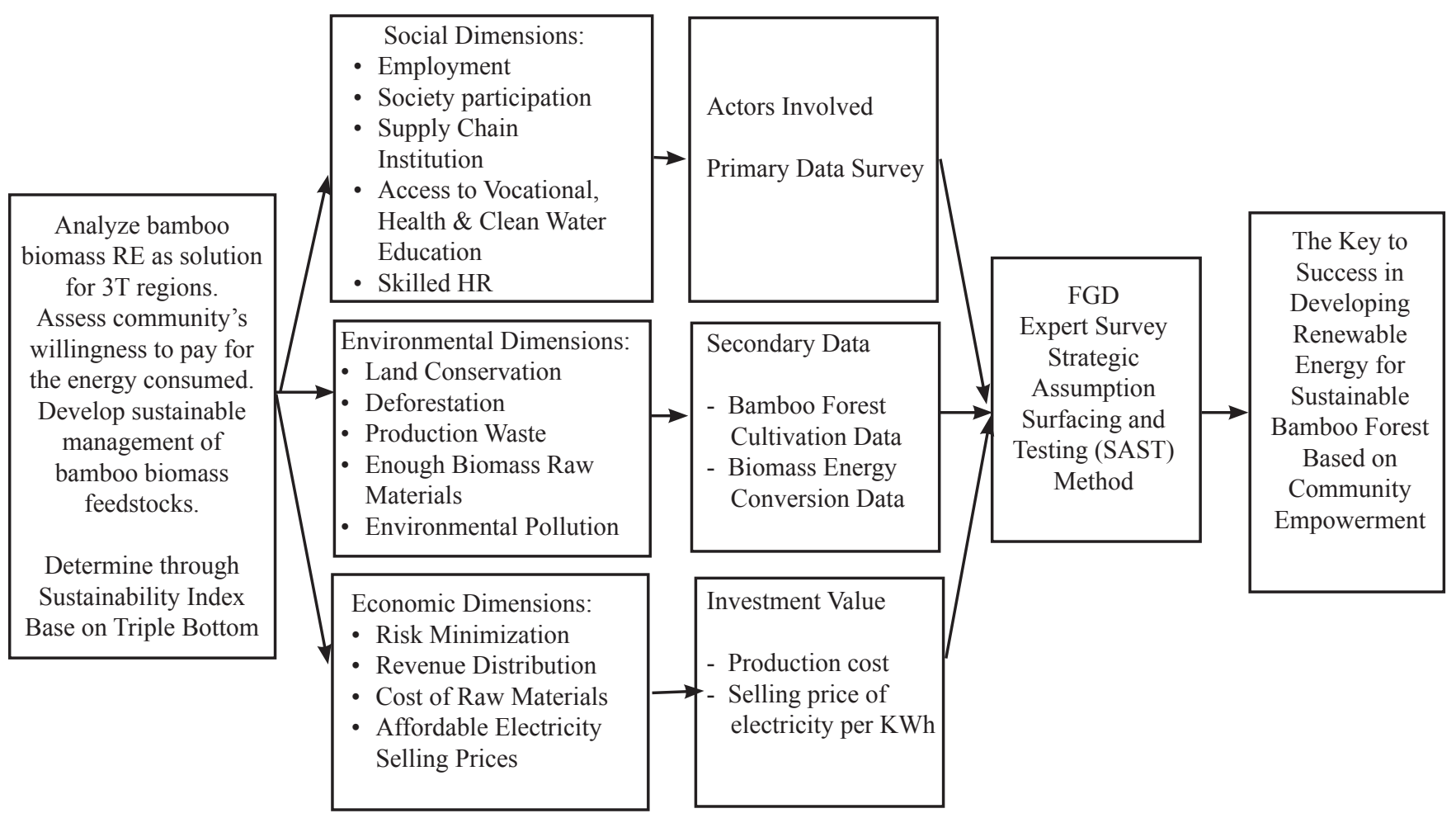

Figure 2. Research Framework 


\section{RESULTS}

The results of the research carried out in the Mentawai Islands District on Siberut Island in 3 target villages i.e.; Madobag Village, Matotonan Village and Saliguma Village in West Sumatra Province, showed that these three villages could be profiles of remote areas in Indonesia that are underdeveloped. The electrification rate for the Mentawai Islands District in general is 27.84 percent for households and 32.45 percent for all users. There are 43 villages in the Mentawai Islands Regency, 23 of which have not yet been entered into by PLN electricity. Therefore, the electrification ratio in Mentawai is currently the lowest compared to all regions in West Sumatra Province. Of all the villages that have been electrified, it is generally located on the coast of the Mentawai islands and is supplied through a Diesel Power Plant (PLTD). The main obstacle faced is the lack of road infrastructure making it difficult for the electricity network to penetrate into the villages in the interior. The geographical condition of the Mentawai Islands, which is located in the tectonic plate area, is vulnerable to earthquakes and tsunamis, so to develop renewable energy facilities it must be in the form of several independent but connected power generation modules for each of the three villages studied. Renewable energy generation is needed so it does not depend on fossil fuels that are not environmentally friendly and expensive for procurement reaching the Mentawai Islands. The choice of renewable energy with the availability of raw materials is bamboo biomass. The choice of downdraft gasification power plants combined with gas engines is the right technology choice, because this technology is low in emissions with a minimal carbon footprint and can be built with a modular system. Table 2, shows the electrification ratio and Table 3, shows the electricity needs in the three villages that are the location of the field research in detail, which illustrates its remote and underdeveloped location so that it can be a case in research on renewable energy development of sustainable bamboo forests based on community empowerment.

\section{Cultural and Socio-Economic Conditions}

The tribe living in the Mentawai islands is called the Mentawai Tribe. Mentawai Islands consists of 4 large islands namely; Siberut Island, Sipora Island, North Pagai Island and South Pagai Island, as well as around 90 other small islands. Among the 4 large islands, Siberut Island is the largest but has the lowest population compared to the others. Their culture and language are very different from the people who live on the island of Sumatra, their culture comes from the neolithic bronze age (1500 BC - $500 \mathrm{BC}$ ), which is seen in the long history of ancient tattoos from the natives. Archaeological research says that the Mentawai tattoo is one of the oldest tattoo traditions in the world (Handani and Azeharie, 2019). The early culture of the Mentawai tribe was the culture of hunting and gathering (huntegatherers) but in its development they also cultivated taro, banThe Mentawai people don't plant rice in the fielanas and sugar cane and raised chickens or pigs. ds. Their staple food is sago, taro and bananas with hunting catches such as wild boar and monkey. While livestock products are usually used for traditional parties. Most natives are professional hunters who use bow and poison arrows (Kurniawan, 2019). Sikerei (shamans) are very important people in the community when they lead ceremonies, cure illnesses, give advice to community members before going hunting, building houses, making canoes, and so on. The Mentawai people live in a traditional residence called Uma which is a house about 15 meters long and 10 meters wide, made by weaving pieces of bamboo to make walls and roofs from straw, the floor of the house on stilts and made of wooden boards. The function of the Uma in addition to a large family residence is also a public meeting hall for ceremonies and traditional parties for its members who are all still bound by kinship according to custom (Nur, 2019).

In the Mentawai customary law there is a belief about the forest. Mentawai people have a belief that areas such as forests, rivers, mountains, hills, forests, seas, and swamps have guardians of spirits called lakokaina. They are sure that this play is very instrumental in bringing in, while holding back their fortune. The Mentawai people believe that all objects in the world have an owner, especially those that concern nature, forests and the environment. Then it is their duty to preserve it. For the Mentawai people, nature and time are very valuable. That is because they live from nature and they hunt in the forest and grow crops in the fields for their daily needs. Nature is used as a place to build their lives, they really appreciate nature and the environment. For example, opening up an area of land to cultivate their land will not burn forest plants but only grab and cut according to the needs of the required field area (Yolanda et al. 2018). 
Tables 2. Electrification ratio

\begin{tabular}{lcccc}
\hline Villlage & Sub-district & Number of Households & Electrification Ratio & Target \\
\hline Madobag & Siberu Selatan & 576 & $6.30 \%$ & $100.00 \%$ \\
Matotonan & Siberut Selatan & 281 & $4.28 \%$ & $100.00 \%$ \\
Saliguma & Siberut Tengah & 394 & $0.00 \%$ & $76.80 \%$ \\
\hline
\end{tabular}

Table 3. Projected electricity demand in 2018

\begin{tabular}{lccccc}
\hline Electricity Needs & Unit & Madobag & Matotonan & Saliguma & Total \\
\hline Households & VA & 201,600 & 98,350 & 137,900 & 437,850 \\
Public Building & VA & 3,900 & 13,000 & 1,300 & 18,200 \\
Schools & VA & 5,200 & 2,600 & 3,900 & 11,700 \\
Medical facility & VA & 2,600 & 1,300 & 2,600 & 6,500 \\
Worship place & VA & 7,800 & 6,500 & 5,200 & 19,500 \\
Port & VA & - & - & 1,300 & 1,300 \\
Clean Water Facilities & VA & 30,000 & 12,500 & 1,300 & 43,800 \\
Street Lighting & VA & 6,250 & 3,750 & 7,500 & 17,500 \\
Total Requirement & VA & 283,000 & 166,100 & 208,500 & 556,350 \\
\hline
\end{tabular}

Source: BPS (2017)

The survey was conducted in Madobag village with a population of 576 households which then sampled 236 households. From the survey results shown in Table 4, it is seen that 73 percent of the sample population are poor families with household expenditure of Rp. 7,780 per day and estimated monthly average income of $\mathrm{Rp}$. 388,950 . The amount of income that is not sufficient with the required energy consumption. Madobag village is geographically located some distance in the interior of the island of Siberut, to achieve it must use the river route by boat pongpong (traditional boat) for 2 hours from Muara Siberut the capital of the Mentawai Islands Regency, so it is very far away for children's school education needs. The results of the survey show a great interest in electricity needs for educational purposes 51 percent and households at 18 percent if the village can be electrified. However, with a low income capability, this village requires economic empowerment for the village community through the development of employment in the Renewable Energy Plants that was built.

The survey was conducted in the village of Matotonan with a population of 281 households which then sampled a total of 166 households. From the survey results shown in table 4 , it is seen that 55 percent of the sample population are poor families with household expenditure of Rp. 7,780 per day and 31 percent are non-poor families with an estimated monthly average income of Rp. 580,750. The village of Matotonan is located in the center of the island of Siberut very far from the district capital. The main livelihoods of the people of the village of Matotonan are gardening and farming, with the main crops being sago (enau), bananas, taro, coconut and plants which are several types of market-oriented plants, such as; chocolate, areca nut, clove, manau and patchouli. The cultivation area is outside the settlement area to the middle of the forest. The results of the survey show a great interest in electricity needs for food refrigerators 27 percent and households 27 percent and education 24 percent if the village can be electrified. The main problem faced by households in the village of Matotonan is the difficulty of obtaining cash. The barter system still dominates transactions between farmers and traders; areca nut, chocolate, manau and rattan are exchanged for sugar, coffee, tea, salt, cooking oil, kerosene and other necessities such as food ingredients for fish and meat so they require refrigerators to store.

The survey was conducted in Saliguma Village with a population of 394 households which were then sampled as many as 198 households. From the survey results shown in table 4 , it is seen that 48 percent of the sample population are poor families with household expenditure of $\mathrm{Rp} 7,780$ per day and 42 percent are non-poor families with an estimated monthly average income of Rp1,071,900. Saliguma is located on the east coast of Siberut Island, the main livelihoods of the people are hunting, gathering forest products and farming. Besides farming, the community also has other livelihoods, such as raising livestock and fishing. The results of the survey show a great interest in the need for electricity for the needs of food refrigerators 17 percent and households at 57 percent and other 
needs 18 percent if the village can be electrified. The Saliguma villagers trade in forest products in a barter manner with the Matotonan villagers and then the forest products are mixed and processed into products that are ready for sale, therefore they need electricity for these needs.

Based on secondary data from the 2017 village census data potential as summarized in table 2 for the target villages, the electrification ratio for Madobag is 6.3 percent, for Matotonan 4.18 percent and for Saliguma 0 percent. Field observations at the site show that there is sporadic electricity production with diesel generators in the target villages. Users are people with regular income, such as village secretaries, teachers, health workers and those employed in other public service work. People who use diesel generators also provide electricity to their closest neighbors. Most diesel generators produce power up to $3 \mathrm{kVA}$, which is used to service from 1 to 5 households from 19:00 to 2:00 every day. The level of use also depends on the number of electrical or electronic devices used in the household, usually television and cell phones. The survey results show that the largest segment of the people living in Madobag, Matotonan, and Saliguma, use kerosene lamps for lighting, while some electric lights come from solar panel batteries. The supply of solar panels and the diesel power generation program was initiated by the district government, but the solar panel batteries had to be replaced every 2 years at a

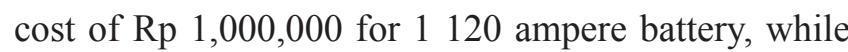
the diesel generators generally functioned well for only 4 to 6 months due to lack of skills and poor operational maintenance.

Tabel 4. Data on the socio-economic survey of the research villages

\begin{tabular}{|c|c|c|c|c|c|c|}
\hline Village & \multicolumn{2}{|c|}{ Madobag } & \multicolumn{2}{|c|}{ Matotonan } & \multicolumn{2}{|c|}{ Saliguma } \\
\hline Total Population & \multicolumn{2}{|c|}{2737} & \multicolumn{2}{|c|}{1357} & \multicolumn{2}{|c|}{1852} \\
\hline Total Household & \multicolumn{2}{|c|}{576} & \multicolumn{2}{|c|}{281} & \multicolumn{2}{|c|}{394} \\
\hline Household Sample Size & \multicolumn{2}{|c|}{236} & \multicolumn{2}{|c|}{166} & \multicolumn{2}{|c|}{198} \\
\hline Parameter & Total & Weight & Total & Weight & Total & Weight \\
\hline \multicolumn{7}{|l|}{ General information } \\
\hline Poor Households (expenses of Rp7,780/ day or less) & 172 & $73 \%$ & 91 & $55 \%$ & 95 & $48 \%$ \\
\hline Near Poor Households (expenses of Rp7,781 - 9,350/ day) & 12 & $5 \%$ & 12 & $7 \%$ & 6 & $3 \%$ \\
\hline Near Non Poor Households (expenses of Rp9,351 - 11,687/ day) & 24 & $10 \%$ & 12 & $7 \%$ & 14 & $7 \%$ \\
\hline Non-Poor Households (expenses of Rp11,688/ day or more) & 28 & $12 \%$ & 51 & $31 \%$ & 83 & $42 \%$ \\
\hline Total Household Samples & 236 & $100 \%$ & 166 & $100 \%$ & 198 & $100 \%$ \\
\hline Estimated Average Household Income per Month & \multicolumn{2}{|c|}{ Rp388,950 } & \multicolumn{2}{|c|}{ Rp580,750 } & \multicolumn{2}{|c|}{ Rp1,071,900 } \\
\hline \multicolumn{7}{|l|}{ Information on Current Energy Use } \\
\hline Genset operating expenses per month & \multicolumn{2}{|c|}{ Rp1,580,000 } & \multicolumn{2}{|c|}{ Rp943,000 } & \multicolumn{2}{|c|}{ Rp943,000 } \\
\hline Number of hours of electricity access per day & \multicolumn{2}{|c|}{12} & \multicolumn{2}{|c|}{16} & \multicolumn{2}{|c|}{16} \\
\hline Number of days of electricity access per month & \multicolumn{2}{|c|}{30} & \multicolumn{2}{|c|}{30} & \multicolumn{2}{|c|}{30} \\
\hline Operating costs of kerosene lamps per month & \multicolumn{2}{|c|}{$\mathrm{Rp} 2,652,000$} & \multicolumn{2}{|c|}{$\mathrm{Rp} 2,945,000$} & \multicolumn{2}{|c|}{ Rp4,640,000 } \\
\hline Hours of using kerosene lamps per day & \multicolumn{2}{|c|}{10} & \multicolumn{2}{|c|}{12} & \multicolumn{2}{|c|}{14} \\
\hline Total operating costs for energy usage per month & \multicolumn{2}{|c|}{ Rp4,232,000 } & $\mathrm{Rp} 3$, & 38,000 & $\mathrm{Rp} 5$, & 83,000 \\
\hline Use of Electricity when The Power Plant Project is running & & & & & & \\
\hline Home lighting and entertainment needs & 42 & $18 \%$ & 45 & $27 \%$ & 113 & $57 \%$ \\
\hline Refrigerator & 24 & $10 \%$ & 45 & $27 \%$ & 34 & $17 \%$ \\
\hline Information needs and tools for learning & 120 & $51 \%$ & 40 & $25 \%$ & 8 & $4 \%$ \\
\hline Domestic business needs & 7 & $3 \%$ & 3 & $2 \%$ & 2 & $1 \%$ \\
\hline Health and hygiene needs & 3 & $1 \%$ & 2 & $1 \%$ & 6 & $3 \%$ \\
\hline Other needs & 40 & $17 \%$ & 30 & $18 \%$ & 36 & $18 \%$ \\
\hline
\end{tabular}


The main occupation of the community is agriculture, but most transactions are bartered locally due to lack of access roads and transportation to markets. More development of road and bridge infrastructure is needed to support the trade of agricultural products from the interior to the sub-urban areas. The Mentawai Islands Regency road network currently consists of main, secondary, local and ring roads, most of which need improvement. The Public Works Service (Dinas Pekerjaan Umum) is targeting $821.70 \mathrm{~km}$ of new road construction in the period 2011 to 2013, but only $174.35 \mathrm{~km}$ of roads were built by the end of 2013. The district government is currently continuing to encourage infrastructure development funded by Local Government Budget funds/APBD (Anggaran Pendapatan dan Belanja Daerah) and government assistance funds from the government center. The community also participated in the construction of roads and bridges through the National Community Empowerment Program/PNPM Mandiri and P2D Mandiri rural development programs.

Villagers around Muara Siberut (the capital city of South Siberut) are allowed to buy up to 10 liters of gasoline or diesel at government subsidized prices, which are sent by tanker to Siberut every 8 to 10 days, depending on the weather. Once the coastal communities receive their quota for the delivery period provided, Muara Siberut fuel suppliers will sell to retailers in 3 districts: South Siberut, Central Siberut and Southwest Siberut. In the interior, retail prices for non-subsidized gasoline and diesel fuel range from Rp15,000 to Rp18,000 and kerosene around Rp9,000. The Madobag, Matotonan, and Saliguma interior communities buy generator fuel at prices above for household appliances and other needs. Lighting is provided by kerosene lamps and electricity for household appliances produced with gasoline or diesel.

\section{Forest Area Mapping and Biomass Availability}

Biomass raw materials for electricity generation in the power plant will be provided by local villagers in the form of freshly harvested bamboo from each of their traditional forest areas. Before harvesting from newly cultivated bamboo can be harvested (in the fourth year of planting), bamboo will be collected from certain traditional bamboo forest areas. For further planning, each head of household in three villages will be asked to meet the production target of planting and cultivation in an area of $0.5-1$ Ha per head of household in a bamboo forest area that is managed in a Community Forest. Development of community bamboo forests is planned to be managed collectively by each village community based on recommendations from the nursery and bamboo seedling greenhouses. Nursery will provide seedlings through the propagation method of tissue culture and develop local nursery seedlings, as well as monitoring planting and cultivation of bamboo. Nursery will cultivate 1 of 9 types of bamboo that grow in Mentawai, i.e. : Petung Bamboo (Dendrocalamus Asper), and cultivation of two (2) new types of bamboo, namely: Bamboo Ampel (Bambusa Vulgaris Vulgaris) and Balku Bamboo (Bambusa Balcooa), because of the three types The bamboo has a high burning value.

The mapping of available forest land is done by mapping each of the forest areas in the three target villages. Each mapped area includes land boundaries, existing important resources, which need to be maintained and areas where crop stock areas are important for daily needs such as food safety and cultural sites are not counted. The remaining area is considered potentially suitable for growing bamboo to supply biomass. The identified land blocks are then grouped using the High Carbon Stock Approach to identify areas of open land, young regeneration forest (shrub), older regeneration forest and dense forest. Dense forest areas (as well as agricultural areas and area of important culturally) are excluded from further calculations for food security because they are not suitable for the development of bamboo forests or may not be touched for biomass supply (Deere et al. 2018).

Using a High Carbon Stock analysis of vegetation in mapped areas, the estimated availability of biomass available for electricity generation can be determined. Usually young regeneration growth contains up to 35 tons of biomass per hectare and most are small trees with diameters of less than $30 \mathrm{~cm}$. From the calculation results it can be estimated that an average of 20 tons of dry biomass conservation is available for biomass power generation from this vegetation strata in all mapped areas. The total available biomass based on conservation estimates from the mapped areas is presented in the Table 5.

The results of the field survey research then become reference data in the FGD and expert surveys. Then results of the discussion are processed using the SAST method to produce key success indicators with a high degree of importance and certainty. On environmental 
dimension, ie; 1) adequate feedstock supply, 2)reduction of environmental damage. On social dimension, i e; 1) community involvement in the supply chain, 2) institutional supply chain. On the economic dimension, i.e.; 1) increase in income of rural communities and 2) sources of electrical energy that are affordable to rural communities. While indicators of success for strategic sustainability that have a high importance but low level of certainty, for environmental dimension are community forest land status is required for bamboo biomass-producing forests, and reforestation in community forest management arrangements. For social dimension is changes in community mindset in community forest management. For economic dimension include; partnerships between communities and power generation project, and electricity distribution must be from PLN to consumers at subsidized rates.

\section{Mapping the Area for Supply of Raw Materials}

The formation of a supplier group is the first stage in the development of sustainable raw materials. Indepth discussions have been held with communities in Madobag, Matatonan and Saliguma to form a socially and culturally acceptable supplier group. This stage is important to begin the process of supplying raw materials, who will have the raw materials, to whom will be given, and initial discussions about prices for raw materials. A summary of the number of households in each village, the number of supplier groups and the number of members in the supplier group per village is presented in Table 6 .
The calculation to determine the extent of raw material for bamboo biomass is based on a conversion rate of $1.3 \mathrm{~kg} / \mathrm{kWh}$ of dried bamboo, which comes from a conversion rate of $55 \%$ for newly harvested bamboo. The amount of bamboo needed for power generation in the 3 target villages is $750 \mathrm{~kW} \mathrm{x} 1.3 \mathrm{~kg} / 0.8 \mathrm{~kg} \times 1.55 \%$ x 365 days x 24 hours x 80\% (power plant capacity factor) or equal to around 11,000 tons harvest biomass per year. Based on recapitulation, presented in Table 7 shows that 3 target villages have $992 \mathrm{Ha}$ of existing bamboo forests, with available biomass of 58,878 tons of ready-to-harvest bamboo. From this bamboo forest area, $60.2 \%$ will need a permit because it is in the forest area. For participatory mapping of the location of the cultivation of new bamboo forests based on local communities resulted in a commitment of 1,508 Ha for bamboo cultivation, with $375 \mathrm{Ha}$ in Madobag; $525 \mathrm{Ha}$ in Matotonan; and $608 \mathrm{Ha}$ in Saliguma. This plotted area will guarantee the availability of long-term and sustainable supply for the development of renewable biomass energy.

\section{Managerial Implications}

Nursery centers are held in three vilages to prepare bamboo forest cultivation. There are 4 superior bamboo species prepared as shown in the following Table 8 . It is planned that 100 seedlings per 1 ha will be distributed to each member of the supplier group, which amounts to 1187 members, so that for 1508 ha the Bamboo Forest Cultivation area can be planted all with an adequate number of seedlings.

Table 5. Land availability for biomass energy

\begin{tabular}{lcccccc}
\hline Village & $\begin{array}{c}\text { Older } \\
\text { Regeneration } \\
\text { Forest Area } \\
\text { (ha) }\end{array}$ & $\begin{array}{c}\text { Estimated } \\
\text { Availability of } \\
\text { Biomass (tons) }\end{array}$ & $\begin{array}{c}\text { Younger } \\
\text { Regeneration } \\
\text { Forest Areas } \\
\text { (ha) }\end{array}$ & $\begin{array}{c}\text { Estimated } \\
\text { Availability of } \\
\text { Biomass (tons) }\end{array}$ & $\begin{array}{c}\text { Availability of } \\
\text { Planted Forest } \\
\text { Areas (ha) }\end{array}$ & $\begin{array}{c}\text { Total Area } \\
\text { Biomass } \\
\text { Availability } \\
\text { (tons) }\end{array}$ \\
\hline Madobag & 3516 & 79411.1 & 165.5 & 3476.8 & 3681.5 & 82887.9 \\
Matotonan & 378.4 & 7767 & 310.4 & 7218 & 688.8 & 14985.0 \\
Saliguma & 781.3 & 17666.7 & 449.2 & 9551 & 1230.5 & 27217.7 \\
TOTAL & 4675.7 & 104844.8 & 925.1 & 20245.8 & 5600.8 & 125090.6 \\
\hline
\end{tabular}

Table 6. Group of Supplier

\begin{tabular}{lccc}
\hline \multicolumn{1}{c}{ Village } & Total Households & Supplier Groups & Number of Suppliers Group Members \\
\hline Madobag & 576 & 10 & 454 \\
Matotonan & 281 & 5 & 285 \\
Saliguma & 394 & 25 & 448 \\
\hline
\end{tabular}


Table 7. Land availability for bamboo cultivation and wood residue biomass

\begin{tabular}{lcccccccc}
\hline \multicolumn{1}{c}{ Village } & $\begin{array}{c}\text { Planting } \\
\text { Forest } \\
\text { Area (ha) }\end{array}$ & $\begin{array}{c}\text { Biomass } \\
\text { Total Area } \\
\text { (dry ton) }\end{array}$ & $\begin{array}{c}\text { Existing } \\
\text { Bamboo } \\
\text { Forest } \\
\text { Area (ha) }\end{array}$ & $\begin{array}{c}\text { Existing } \\
\text { Bamboo } \\
\text { Biomass } \\
\text { (dry ton) }\end{array}$ & $\begin{array}{c}\text { Bamboo } \\
\text { Forest } \\
\text { Cultivation } \\
\text { Area (ha) }\end{array}$ & $\begin{array}{c}\text { Bamboo } \\
\text { Forest } \\
\text { Cultivation } \\
\text { Biomass } \\
\text { (dry ton) }\end{array}$ & $\begin{array}{c}\text { Wood } \\
\text { Residue }\end{array}$ & $\begin{array}{c}\text { Wood } \\
\text { Residue } \\
\text { (ha) }\end{array}$ \\
\hline Madobag & 3681.5 & 82887.9 & 783 & 46473.3 & 375 & 8375.4 & 2523.5 & $\begin{array}{c}\text { Biomass } \\
\text { (dry ton) }\end{array}$ \\
Matotonan & 688.8 & 14985 & 47 & 2789.6 & 525 & 11725.6 & 116.8 & 469.8 \\
Saliguma & 1230.5 & 27217.7 & 162 & 9615.2 & 608 & 13579.3 & 460.5 & 4023.2 \\
TOTAL & 5600.8 & 125090.6 & 992 & 58878 & 1508 & 33680.3 & 3100.8 & 32532.3 \\
\hline
\end{tabular}

Table 8 . Supreme quality bamboo shoot nurseries

\begin{tabular}{lccccc}
\hline $\begin{array}{c}\text { Nursery } \\
\text { Location }\end{array}$ & $\begin{array}{c}\text { Dendro calamus } \\
\text { Asper }\end{array}$ & $\begin{array}{c}\text { Bambusa Balcooa var. } \\
\text { Capensis }\end{array}$ & $\begin{array}{c}\text { Bambusa } \\
\text { Balcooa }\end{array}$ & $\begin{array}{c}\text { Bambusa Vulgaris } \\
\text { Vulgaris }\end{array}$ & Total \\
\hline Matotonan & 36770 & 12400.0 & 7999 & 1960 & 59129 \\
Madobag & 28200 & 8186 & 5229 & 1300 & 42915 \\
Saliguma & 34400 & 9575 & 5085 & 1525 & 50585 \\
TOTAL & 99370 & 30161.0 & 18313 & 4785 & 152629 \\
\hline
\end{tabular}

In Saliguma, Matotonan and Madobag, a group of village suppliers will prepare a shelter as a place to collect raw materials until they are dry. Bamboo biomass is prepared in one meter cut sizes and in dry conditions in a shelter. Then the dry biomass will be transported to the power plant. Chipping or cutting will be done in the Power Plant area using a cutting tool that has the capacity to cut $1 \mathrm{~m}$ of bamboo into $5 \mathrm{~cm}$ long. Before the gasifier is processed, this dry biomass will be processed dryier / drying to reduce the water content to 20 percent. The following time schedule Table 9 shows the process of supply biomass from harvest begins by marking harvestable bamboo culms until it ends with delivery to the power plant as chips. The supply of bamboo biomass raw materials takes one month before the energy conversion process at the power plant. The time schedule below is for each requirement of 5-6 tons.

Based on the stages of the bamboo biomass supply process which requires quite a long time and each power plant requires a continuous delivery of 5 tons of uninterrupted daily, a supply chain institution is needed that can guarantee the supply of biomass needed. This supply chain is based on an electricity cooperation scheme whose main purpose is the welfare of the perpetrators so that it can run well. To achieve this, it is necessary to have an equitable distribution of income in the supply chain (Marimin et al. 2014).

\section{The Electricity Needs of Village Communities}

The following table below is a calculation of electricity needs based on data obtained from the results of a research survey. Seen in the table, the majority of 61 percent of households are below the poverty line, only 26 percent of households are not poor. The highest average household income in Saliguma village is Rp1,071,900.00 only 50 percent of the West Sumatra Province Minimum Wage. While the lowest Madobag village is Rp388,950.00 only 18 percent of the West Sumatra Province Minimum Wage. On the other hand, to get electricity through a diesel generator requires costs above the average monthly income and for the purposes of lighting with kerosene lamps requires even greater costs. Seeing the conditions mentioned above, development efforts through the development of electrical energy without community empowerment and without the presence of PLN with subsidized tariffs will not succeed, because the people in the three target villages will not be able to buy electricity.

Estimated results to meet the needs of every household requires a minimum electrical power of 350 Volt Amperes (VA / Watt). The minimum power that can be provided by PLN is 450 VA with a subsidy rate of Rp415 per kwh. If it is estimated that the average household electricity consumption per day is 16 hours, then the cost of electricity that must be spent per household is 16 x 0.45 x 30 x Rp. 415 or equal to Rp89,600 per month. The estimated electricity demand for public facilities in the three target villages is $131,350 \mathrm{VA}$, and the needs of 
all 1251 households are 437,850 VA. When adding up the total electricity demand for the three target villages is $569,200 \mathrm{VA}$ or around $570 \mathrm{KW}$ where the installed capacity for the three biomass power plants is $700 \mathrm{KW}$ will meet these needs, as shown on Table 10.

\section{Willingness to Pay for Village Communities Electricity}

Willingness to pay can be interpreted as the economic value of people who want to sacrifice goods and services to get other goods and services (Sugiyanthi et al, 2020). Willingness to Pay for electricity can also be calculated by how much household economic empowerment can provide additional income above the obligation to pay electricity vouchers per month. The power plant will buy bamboo biomass from the supplier group at a price of Rp150/kg. Biomass needs for the three plants per month are 900 tons (at full capacity). The cost of raw materials is $900000 \mathrm{~kg} \times \mathrm{Rp} 150$ or Rp135,000,000 per month. If each household totaling 1251 is represented in the supplier group, each household will receive $\mathrm{Rp}$.
100,000 per month. This calculation on paper exceeds the obligation to pay for electricity, but there is a need for supply chain institutions to ensure the supply of biomass raw materials and the distribution of income.

\section{CONCLUSION AND RECOMMENDATIONS}

\section{Conclusions}

The results study showed that electrification ratios in the three target villages were still very low, averaging around 5 percent. For the development of underdeveloped villages, there is a need for electricity supply to prosper the village community. The geographical conditions of the Mentawai Islands are in the tectonic plate area which is prone to earthquakes and tsunamis, and field conditions no adequate infrastructure and no transmission network then the best solution is a separate independent generating module in each of the three villages.

Table 9. Bamboo supply process phase

\begin{tabular}{|c|c|c|c|c|c|c|c|c|c|c|}
\hline \multirow{2}{*}{ Phases } & \multicolumn{10}{|c|}{ Number of days needed } \\
\hline & 1 & 2 & $3-10$ & 11 & 12 & 13 & $14-24$ & 25 & 26 & 27 \\
\hline \multicolumn{11}{|l|}{ Bamboo stem selection and markers } \\
\hline \multicolumn{11}{|l|}{ Harverst Cut bamboo stems } \\
\hline \multicolumn{11}{|l|}{ Drying upright bamboo stems (7 days) } \\
\hline \multicolumn{11}{|l|}{ Moving to the side of the road } \\
\hline \multicolumn{11}{|l|}{ Delivery to the collection point } \\
\hline \multicolumn{11}{|l|}{ Cutting bamboo $5-10 \mathrm{~cm}$ in chip size } \\
\hline \multicolumn{11}{|l|}{ Bamboo chip drying (10 days) } \\
\hline \multicolumn{11}{|l|}{ Chip storage ( 2 days) } \\
\hline Delivery to the Plant ( 5 tons / day) & & & & & & & & & & \\
\hline
\end{tabular}

Table 10. Electrical power needs

\begin{tabular}{|c|c|c|c|c|c|c|}
\hline Electrical Power Needs & Madobag & Matotonan & Saliguma & Total & $\begin{array}{c}\text { Total } \\
\text { Power (VA) }\end{array}$ & $\begin{array}{l}\text { Power User } \\
\text { by Segment }\end{array}$ \\
\hline Households & 576 & 281 & 394 & 1,251 & 437,850 & $76.92 \%$ \\
\hline \multicolumn{7}{|l|}{ Public Facilities } \\
\hline Industrial facilities with a capacity of $5000 \mathrm{VA}$ & 2 & 1 & 3 & 6 & 30,000 & $5.27 \%$ \\
\hline Business facilities with a capacity of $5000 \mathrm{VA}$ & 2 & 1 & 5 & 8 & 40,000 & $7.03 \%$ \\
\hline $\begin{array}{l}\text { Houses of Worship \& Health Centers cap. of } \\
1350 \text { VA }\end{array}$ & 3 & 3 & 3 & 9 & 12,150 & $2.13 \%$ \\
\hline Educational facilities capacity of $1350 \mathrm{VA}$ & 2 & 2 & 2 & 6 & 8,100 & $1.42 \%$ \\
\hline Village Government Office capacity of 1350 VA & 2 & 2 & 2 & 6 & 8,100 & $1.42 \%$ \\
\hline $\begin{array}{l}\text { Public Lighting Facilities \& Roads @100 VA } \\
\text { LED lamps }\end{array}$ & 110 & 110 & 110 & 330 & 33,000 & $5.80 \%$ \\
\hline $\begin{array}{l}\text { Total Household Needs and Public Facilities for } \\
\text { Electricity }\end{array}$ & 697 & 400 & 519 & 1,616 & 569,200 & $100.00 \%$ \\
\hline
\end{tabular}


The technology needed is renewable energy generation so that it does not depend on fossil fuels that are not environmentally friendly and costly to procure to reach the Mentawai Islands. The choice of renewable energy that allows according to the availability of available raw materials is bamboo biomass. With the availability of bamboo forest biomass and with adequate community management of bamboo forest, the choice of downdraft gasification power plant combined with gas engine is a suitable choice, because this technology is low in emissions with minimal carbon footprint and can be built with a modular system.

The survey results also found that households without access to electricity use kerosene for lighting while those who have access to electricity from generators use it for lighting, fans, radios, televisions and cellphone charging batteries. Other energy consumption, such as firewood for cooking, remains the same for the three villages. Kerosene which is replaced by electric lighting is a cost saving resource for the economy and provides economic benefits. The price paid for kerosene lighting is an indication of Willingness to Pay for the amount of lighting consumed.

The results also showed the safety of raw materials can be met in the bamboo biomass that has been available in the forest and the needs of community bamboo forest cultivation with superior bamboo seeds have been planned and adjusted to the specifications of the biomass power plant. Coupled with biomass reserves from wood residues available in the forest, it is estimated that the security of raw material supply is more than sufficient for the three biomass plants.

Sustainable development of biomass renewable energy can only be maintained by creating bamboo forests that are managed with the support of the entire village community. Only in this way, power generation from local biomass sources is guaranteed for its long-term sustainability. Community-managed bamboo forests for the supply of biomass raw materials to power plants are an integral part.

The results of the study show that if the empowerment of rural communities can run through their participation as suppliers of bamboo raw materials, then their income as suppliers will be able to increase their ability to pay for PLN subsidized electricity. In order for villagers to be involved in the development of renewable energy in the supply chain and as a power plant operator, a fair and equitable distribution of income is needed between the risks and the results of their work.

\section{REFERENCES}

Ardian et al. 2018. Multi stakeholder engagement in indonesia sustainable palm oil governance. Jurnal Manajemen dan Agribisnis 15(1):96-105. https://doi.org/10.17358/jma.15.1.96.

Ashby MF. 2016. Bamboo for sustainable flooring. Materials and Sustainable Development 2016: 197-210. https://doi.org/10.1016/B978-0-08100176-9.00013-X.

Cambero C, Sowlati T. 2014. Assessment and optimization of forest biomass supply chains from economic, social and environmental perspectives - a review of literature. Renewable and Sustainable Energy Reviews 36: 62-73. https://doi.org/10.1016/j.rser.2014.04.041.

Chen CW, Fan Y. 2012. Bioethanol supply chain system planning under supply and demand uncertainties. Transportation Research Part E: Logistics and Transportation Review 48(1):150-64.

Cidhy DATK, Baga LM, Djohar S. 2015. Pariwisata kreatif dan kegiatan ekstrakurikuler berbasis bambu dalam pengembangan model bisnis cv suratin bamboo. Jurnal Manajemen Dan Agribisnis 13(3):227-39.

Deere NJ et al. 2018. High carbon stock forests provide co-benefits for tropical biodiversity. Journal of Applied Ecology 55(2):997-1008.

Dhyani V, Bhaskar T. 2018. A comprehensive review on the pyrolysis of lignocellulosic biomass. Renewable Energy 129: 695-716. https://doi. org/10.1016/j.renene.2017.04.035.

Gimenez C, Tachizawa EM. 2012. Extending sustainability to suppliers: a systematic literature review. Supply Chain Management: An International Journal 17(5):531-43.

GoldS.2011.Bio-energy supply chains and stakeholders. Mitigation and Adaptation Strategies for Global Change 16(4):439-62.

Hall J, Matos S. 2010. Incorporating impoverished communities in sustainable supply chains. International Journal of Physical Distribution \& Logistics Management 40(1/2):124-47.

Handani I, Azeharie S. 2019. Analisis semiotika tato tradisional suku mentawai. Koneksi 3(1): 49-55. https://doi.org/10.24912/kn.v3i1.6144.

Hennig C, Brosowski A, Majer S. 2016. Sustainable 
feedstock potential - a limitation for the biobased economy? Journal of Cleaner Production 123:200-202.https://doi.org/10.1016/j. jclepro.2015.06.130.

Hong C et al. 2011. Comparative growth, biomass production and fuel properties among different perennial plants, bamboo and miscanthus. Botanical Review 77(3):197-207.

International Network for Bamboo \& Rattan. 2014. Bamboo: a strategic resource for countries to reduce the effects of climate change. Policy Synthesis Report 1-28.

Kerlero de Rosbo, Guillaume, de Bussy J. 2012. Electricalvalorization of bamboo in Africa. INBAR 1-59.

Koirala et al. 2016. Energetic communities for community energy: a review of key issues and trends shaping integrated community energy systems. Renewable and Sustainable Energy Reviews 56: 722-744. https://doi.org/10.1016/j. rser.2015.11.080.

Kondrasheva N. 2015. Sustainable biofuels. Open Journal of Chemical Engineering and Science. https://doi.org/10.15764/OJCES.2015.01001.

Kurniawan R. 2019. Harmonisasi Masyarakat Mentawai. Al-Qalb: Jurnal Psikologi Islam 9(2): 111-118. https://doi.org/10.15548/alqalb. v9i2.859.

Lautala PT et al. 2015. Opportunities andchallenges in the design and analysis of biomass supply chains. Environmental Management 56(6):1397-1415.

Li X et al. 2019. Assimilating spatiotemporal modis lai data with a particle filter algorithm for improving carbon cycle simulations for bamboo forest ecosystems. Science of the Total Environment 694:133803.https://doi.org/10.1016/j. scitotenv.2019.133803.

Little S. 2017. A delphi study on risk and uncertainty decision making for renewable energy green supply chain management. Northcentral University of Arizona.

Lobovikov M, Schoene D, Yping L. 2012. Bamboo in climate change and rural livelihoods. Mitigation and Adaptation Strategies for Global Change 17(3):261-76.

Marimin et al. 2014. Valuechain analysis for green productivity improvement in the natural rubber supply chain: a case study. Journal of Cleaner Production 85:201-211.
Medeiros DL, Sales EA, Kiperstok A. 2015. Energy production from microalgae biomass: carbon footprint and energy balance. Journal of Cleaner Production 96: 493-500. https://doi. org/10.1016/j.jclepro.2014.07.038.

Nuhoff et al. 2016. Sustainability benefits and challenges of inter-organizational collaboration in bio-based business: a systematic literature review. Sustainability 8(4):307.

Nur M. 2019. Sikerei dalam cerita: penelusuran identitas budaya mentawai. Jurnal Masyarakat Dan Budaya.

Partey et al. 2017. Potentials of bamboo-based agroforestry for sustainable development in subsaharan africa: a review. Agricultural Research 6(1):22-32.

Sharma B. et al. 2013. Biomasssupply chain design and analysis: basis, overview, modeling, challenges, and future. Renewable and Sustainable Energy Reviews 24:608-627. https://doi.org/10.1016/j. rser.2013.03.049.

Sofiana Y, Wahidiyat M, Caroline OS. 2018. Bamboo as sustainable material for furniture design in disaster and remote areas in Indonesia. in IOP Conference Series: Earth and Environmental Science 126.

Sritong C, Kunavongkrit A, Piumsombun C. 2012. Bamboo : an innovative alternative raw material for biomass power plants. International Journal of Innovation, Management and Technology 3(6):759-62.

Sugiyanthi D, Nurmalina R, Novianti T. 2020. Sikap konsumen dan willingness to pay (wtp) pada produk buavita royale. Jurnal Aplikasi Bisnis Dan Manajemen 6(2): 303. https://doi.org/10.17358/ jabm.6.2.303.

Truong AH, Le TMA. 2014. Overview of Bamboo Biomass for Energy Production. Hal 24 pages.

Yolanda et al. 2018. Kearifan lokal arat sabulungan dalam pengelolaan hutan (studi kasus hutan adat suku saerajen dan Suku Samongilailai Di Desa Malacan Kecamatan Siberut Utara Kabupaten Kepulauan Mentawai). Jurnal Buana 2(3):795805.

Youssefian S, Rahbar N. 2015. Molecular origin of strength and stiffness in bamboo fibrils. Scientific Reports 5, 11116 (2015). https://doi.org/10.1038/ srep11116. 